\title{
Relation between the Actual and Estimated Maximum Ground Level Concentration of Air Pollutant and Its Downwind Locations
}

\author{
Khaled S. M. Essa*, Soad M. Etman, Maha S. El-Otaify \\ Mathematics and Theoretical Physics Department, NRC/AEA, Cairo, Egypt \\ Email: *mohamedksm56@yahoo.com
}

How to cite this paper: Essa, K.S.M., Etman, S.M. and El-Otaify, M.S. (2020) Relation between the Actual and Estimated Maximum Ground Level Concentration of Air Pollutant and Its Downwind Locations Open Journal of Air Pollution, 9, 27-35. https://doi.org/10.4236/ojap.2020.92003

Received: December 16, 2019

Accepted: June 27, 2020

Published: June 30, 2020

Copyright (c) 2020 by author(s) and Scientific Research Publishing Inc. This work is licensed under the Creative Commons Attribution International License (CC BY 4.0).

http://creativecommons.org/licenses/by/4.0/

\begin{abstract}
In this work we used the Gaussian plume model to calculate the actual maximum ground level concentration (MGLC) of air pollutant and its downwind location by using different systems of dispersion parameters and for different stack heights. An approximate formula for the prediction of downwind position that produces the MGLC of a pollutant based on the Gaussian formula was derived for different diffusion parameters. The derived formula was used to calculate the approximate MGLC. The actual and estimated values are presented in tables. The comparison between the actual and estimated values was investigated through the calculation of the relative errors. The values of the relative errors between the actual and estimated MGLC lie in the range from: 0 to 70.2 and 0 to 1.6 for Pasquill Gifford system and Klug system respectively. The errors between the actual and estimated location of the MGLC lies in the range from: 0.2 to 227 and 0.7 to 9.4 for Pasquill Gifford system and Klug system respectively.
\end{abstract}

\section{Keywords}

Gaussian Plume Model, Actual and Estimated Values, Relative Errors

\section{Introduction}

The atmospheric diffusion models that are widely used for regulatory purposes have been reviewed by [1]. The most important parameters predicted by these models are the magnitude and location of the maximum ground level concentration. The Gaussian Plume Model (GPM) is a widely used dispersion model in more regulatory applications than the other models. It was derived by many authors such as [2] [3] [4] [5]. Maximum ground level concentration of air pollu- 
tant was studied by [6].

The GPM has been expressed in terms of the horizontal and vertical diffusion parameters, $\sigma_{y}(x)$ and $\sigma_{z}(x)$. Different formulae for $\sigma_{y}(x)$ and $\sigma_{z}(x)$ have been collected from different References and presented by [7].

The concentration of a pollutant is a function of a number of variables, such as the emission rate, the location of the receptor from the source and the atmospheric conditions as: wind speed, wind direction and the vertical temperature changes in the local atmosphere.

The major purpose of the present study is to derive an approximate formula for estimating the downwind location of the maximum concentration that is used to find the MGLC of the released pollutant based on the Gaussian model.

The actual MGLC of air pollutant and its location was calculated by using the Gaussian formula for different dispersion parameters $\sigma_{y}(x)$ and $\sigma_{z}(x)$, and different stack heights. Different formulae of $\sigma_{z}(x)$ are used to derive an approximate formula for the downwind location of the maximum concentration that is used to predict the approximate MGLC.

The actual and estimated values are presented in tables. The comparison between the actual and estimated values was investigated through the calculation of the relative errors.

\section{Model Description}

The Gaussian plume model for estimating the concentration of pollutant released from a continuous point source at some point above the ground is given by [8] [9]:

$$
C(x, y, z, H)=\frac{Q}{2 \pi u \sigma_{y} \sigma_{z}} \mathrm{e}^{-y^{2} / 2 \sigma_{y}^{2}}\left[\mathrm{e}^{-(z-H)^{2} / 2 \sigma_{z}^{2}}+\mathrm{e}^{-(z+H)^{2} / 2 \sigma_{z}^{2}}\right]
$$

where,

$C=$ Concentration of pollutant in air $\left(\mathrm{g} \cdot \mathrm{m}^{-3}\right)$,

$Q=$ Emission rate $\left(\mathrm{g} \cdot \mathrm{s}^{-1}\right)$,

$u=$ Wind speed at the effective release height $\left(\mathrm{m} \cdot \mathrm{s}^{-1}\right)$,

$x=$ Downwind distance from the source $(\mathrm{m})$,

$y=$ Lateral distance from the plume center line $(\mathrm{m})$,

$z=$ Vertical height above ground $(\mathrm{m})$,

$H=$ Effective release height above the ground (m),

$\sigma_{y}$ and $\sigma_{z}$ are the lateral and vertical dispersion parameters $(\mathrm{m})$.

The second exponential term within the brackets is the term due to reflection at the ground surface. The ground level concentration for an elevated release below the centerline of the plume is obtained by setting $y$ and $z=0$ in Equation (1):

$$
C(x, 0,0, H)=\frac{Q}{\pi u \sigma_{y} \sigma_{z}} \exp \left[-\frac{H^{2}}{2 \sigma_{z}^{2}}\right]
$$

The variables $\sigma_{y}$ and $\sigma_{z}$ depend on the downwind distance from the source $(x)$, and the atmospheric stability. 
The actual MGLC below the plume centerline $\left(C_{\text {ma }}\right)$ and its location $\left(x_{m a}\right)$ can be calculated by using Equation (2). The rough estimation of the position of the $\operatorname{MGLC}\left(x_{m e}\right)$ is calculated [10]:

$$
\sigma_{z}=\frac{H}{\sqrt{2}}
$$

Therefore, the rough estimation of the MGLC can be calculated from the following equation at $x=x_{m e}$ :

$$
C_{m e}(x, 0,0, H)=\frac{2 Q}{\pi e u H^{2}}\left(\frac{\sigma_{z}}{\sigma_{y}}\right)
$$

The formula of $X_{m e}$ can be derived by solving Equation (3) using different systems of the vertical diffusion parameters [11] as follows:

\subsection{Pasquill-Gifford System}

The values of $\sigma_{y}$ and $\sigma_{z}$ as functions of distance for use with his suggested stability categories were suggested by [12]. The modified values of $\sigma_{y}$ and $\sigma_{z}$ for use with the original Pasquill stability categories were suggested by [13]. The combination of Pasquill and Gifford parameters is called P-G scheme. In this scheme $\sigma_{y}$ and $\sigma_{z}$ are obtained from graphs as a function of downwind distance, $x$, for each stability class. These curves can be approximated by the following equations [14]

$$
\begin{gathered}
\sigma_{y}(x)=\left(a_{1} \ln x+a_{2}\right) x \\
\sigma_{z}(x)=\frac{1}{2.15} \exp \left(b_{1}+b_{2} \ln x+b_{3} \ln ^{2} x\right)
\end{gathered}
$$

where the constants $a_{1}, a_{2}, b_{1}, b_{2}$, and $b_{3}$ depend on the atmospheric stability and their values are presented in Table 1 .

From Equation (6) and Equation (3) we find the formula of the estimated position of the MGLC as:

$$
x_{m e}=\exp \left(\frac{-b_{2} \pm \sqrt{b_{2}^{2}-4 b_{3}\left[b_{1}-\ln \left(\frac{2.15 H}{\sqrt{2}}\right)\right]}}{2 b_{3}}\right)
$$

Table 1. Coefficient of the Pasquill-Gifford system for all stability classes [14]

\begin{tabular}{ccccccc}
\hline Coefficient & \multicolumn{5}{c}{ Stability } & Categories \\
\hline & $\mathrm{A}$ & $\mathrm{B}$ & $\mathrm{C}$ & $\mathrm{D}$ & $\mathrm{E}$ & $\mathrm{F}$ \\
\hline$a_{1}$ & -0.0234 & -0.0147 & -0.0117 & -0.0059 & -0.0059 & -0.0029 \\
$a_{2}$ & 0.3500 & 0.2480 & 0.1750 & 0.1080 & 0.0880 & 0.0540 \\
$b_{1}$ & 0.8800 & -0.9850 & -1.1860 & -1.3500 & -2.8800 & -3.8000 \\
$b_{2}$ & 0.1520 & 0.8200 & 0.8500 & 0.7930 & 1.2550 & 1.4190 \\
$b_{3}$ & 0.1475 & 0.0168 & 0.0045 & 0.0420 & -0.0420 & -0.0550 \\
\hline
\end{tabular}


where, the positive square root is selected to estimate $x_{m e}[14]$.

\subsection{Power Law Method (Klug System)}

Specified a system of diffusion parameters that is applicable for short-term ground-level release over terrain with a low surface roughness [15] [16]. Klug does not exceed source distances of 2 or $3 \mathrm{~km}$. In this range the diffusion parameters can be described by power law functions as:

$$
\begin{aligned}
& \sigma_{y}(x)=p_{y} x^{q_{y}} \\
& \sigma_{z}(x)=p_{z} x^{q_{z}}
\end{aligned}
$$

where the coefficients $p$ and $q$ are specified in Table 2. The formula of the estimated location of the MGLC will be as:

$$
x_{m e}=\left(\frac{H}{\sqrt{2} P_{z}}\right)^{\frac{1}{q_{z}}}
$$

\subsection{Standard Scheme}

In this scheme, the crosswind dispersion parameter $\sigma_{y}(x)$ and the vertical dispersion parameter $\sigma_{z}(x)$ for various stability classes can be analytically expressed based on Pasquill-Gifford (P-G) curves as follows [17]:

$$
\begin{gathered}
\sigma_{y}=\frac{r x}{(1+x / a)^{p}} \\
\sigma_{z}=\frac{s x}{(1+x / a)^{q}}
\end{gathered}
$$

where $r, s, a, p$ and $q$ are constants depending on the atmospheric stability. Their values are given in Table 3 (Green et al., 1980). The derived formula of the estimated location of the MGLC is:

$$
x_{m e}=\frac{a}{q-1}
$$

The actual MGLC $\left(C_{m a}\right)$ and its location $\left(x_{m a}\right)$ were calculated by using Equation (2) by differentiating it with respect to " $X$ " and equate the result with zero, then find the value of maximum downwind distance and substituting in Equation (2) to find the actual MGLC. Equation (7), Equation (10) and Equation (13)

Table 2. Values of parameters of the power law (Klug System) for all stability classes [14].

\begin{tabular}{ccccccc}
\hline Coefficient & \multicolumn{5}{c}{ Stability } & Categories \\
\hline & $\mathrm{A}$ & $\mathrm{B}$ & $\mathrm{C}$ & $\mathrm{D}$ & $\mathrm{E}$ & $\mathrm{F}$ \\
\hline$p_{y}$ & 0.4690 & 0.3060 & 0.2300 & 0.2190 & 0.2370 & 0.2730 \\
$q_{y}$ & 0.9030 & 0.8850 & 0.8550 & 0.7640 & 0.6910 & 0.5940 \\
$p_{z}$ & 0.0170 & 0.0720 & 0.0760 & 0.1400 & 0.2170 & 0.2620 \\
$q_{z}$ & 1.3800 & 1.0210 & 0.8790 & 0.7270 & 0.6100 & 0.5000 \\
\hline
\end{tabular}


Table 3. Values of the dispersion parameters corresponding to Pasquill stability.

\begin{tabular}{cccccc}
\hline Atmospheric & & \multicolumn{3}{c}{ Stability } & Categories \\
\hline Stability & $r(\mathrm{~m} / \mathrm{km})$ & $s(\mathrm{~m} / \mathrm{km})$ & $a(\mathrm{~km})$ & $p$ & $q$ \\
\hline A & 250 & 102 & 0.927 & 0.189 & -0.918 \\
B & 202 & 96.2 & 0.37 & 0.162 & -0.101 \\
C & 134 & 72.2 & 0.283 & 0.134 & 0.102 \\
D & 78.7 & 47.5 & 0.707 & 0.135 & 0.465 \\
E & 56.6 & 33.5 & 1.07 & 0.137 & 0.624 \\
F & 37 & 22 & 1.17 & 0.134 & 0.70
\end{tabular}

are used to estimate the location of the MGLC $\left(x_{m e}\right)$. The values of $x_{m e}$ are used to estimate the values of the MGLC by using Equation (4). The maximum concentrations of pollutant and their downwind locations were calculated using $Q=$ $3 \mathrm{~g} / \mathrm{s}$ and $u=3 \mathrm{~m} / \mathrm{s}$ for different effective heights $(5 \mathrm{~m}, 45 \mathrm{~m}, 100 \mathrm{~m}$, and $250 \mathrm{~m}$ ) and different atmospheric stabilities. The comparison between the actual and estimated values is investigated through the calculation of the relative error:

$$
\text { Relative error }=\left|\frac{\text { actual value }- \text { estimated value }}{\text { actual value }}\right|
$$

The results of this study are presented in Tables 4-6.

\section{Results and Discussion}

The actual and estimated maximum ground level concentrations of pollutant and their downwind locations were calculated using "emission rate" $Q=3 \mathrm{~g} / \mathrm{s}$ and "wind speed" $u=3 \mathrm{~m} / \mathrm{s}$ for different effective source heights $(5 \mathrm{~m}, 45 \mathrm{~m}, 100$ $\mathrm{m}$, and $250 \mathrm{~m}$ ) and for different atmospheric stabilities.

We see from Equation (7), Equation (10) and Equation (13) that the formula for $x_{m e}$ derived by using Pasquill-Gifford system and Power law method is dependent on the stability of air and the effective source height $(H)$, while the derived formula using the Standard scheme was found to be dependent on the atmospheric stability only.

The results of this study are presented in tables. The comparisons between the actual and estimated values are investigated through the calculation of the relative error.

Tables 4-6 reveal that for each effective stack height $(H)$ as the atmospheric stability tends to be stable both the actual and estimated position of the MGLC tends to be far from the stack except for stability class B at $H=5 \mathrm{~m}$ in Table 5 . Also, the increase in the effective source height gives the same trend. These tables clarify that for each stability class the higher $H$ gives the lower and the more distant concentration.

\section{Conclusions}

From Table 4 for Pasquill Gifford system, one can see that higher $H$ gives higher error for the estimation of maximum concentration $\left(C_{m}\right)$ and its location $\left(x_{m}\right)$. 
Table 4. Relation between actual and estimated values for MGLC and its location using Pasquill-Gifford system for different stack heights.

\begin{tabular}{|c|c|c|c|c|c|c|}
\hline $\begin{array}{l}\text { Stability } \\
\text { class }\end{array}$ & $\begin{array}{r}C_{m a} \\
\mathrm{~g} / \mathrm{m}^{3}\end{array}$ & $\begin{array}{c}X_{m a} \\
\mathrm{~m}\end{array}$ & $\begin{array}{r}C_{m e} \\
\mathrm{~g} / \mathrm{m}^{3}\end{array}$ & $\begin{array}{c}X_{m e} \\
\mathrm{~m}\end{array}$ & $\begin{array}{l}\text { Relative } \\
\qquad C_{m}\end{array}$ & $\begin{array}{c}\text { Error\% } \\
\quad x_{m}\end{array}$ \\
\hline \multicolumn{7}{|c|}{$H=5 \mathrm{~m}$} \\
\hline A & $1.101 \mathrm{E}-2$ & 9.9 & $1.099 \mathrm{E}-2$ & 10.2 & 0.1 & 3.6 \\
\hline B & $5.415 \mathrm{E}-3$ & 31.3 & $5.415 \mathrm{E}-3$ & 31.0 & 0.0 & 0.2 \\
\hline $\mathrm{C}$ & $6.172 \mathrm{E}-3$ & 40.4 & $6.171 \mathrm{E}-3$ & 40.8 & 0.0 & 1.0 \\
\hline $\mathrm{D}$ & $5.926 \mathrm{E}-3$ & 64.6 & $5.910 \mathrm{E}-3$ & 67.4 & 0.3 & 4.4 \\
\hline $\mathrm{E}$ & $5.339 \mathrm{E}-3$ & 101.1 & $5.338 \mathrm{E}-3$ & 102.3 & 0.0 & 1.2 \\
\hline \multirow[t]{2}{*}{$\mathrm{F}$} & $5.036 \mathrm{E}-3$ & 164.5 & $5.032 \mathrm{E}-3$ & 168.3 & 0.1 & 2.3 \\
\hline & & & $H=45 \mathrm{~m}$ & & & \\
\hline A & $2.086 \mathrm{E}-4$ & 77.2 & $2.094 \mathrm{E}-4$ & 71.9 & 1.2 & 6.9 \\
\hline B & $7.575 \mathrm{E}-5$ & 304.1 & $7.565 \mathrm{E}-5$ & 296.1 & 0.1 & 2.6 \\
\hline C & $7.521 \mathrm{E}-5$ & 478.8 & $7.521 \mathrm{E}-5$ & 476.0 & 0.0 & 0.6 \\
\hline $\mathrm{D}$ & $5.528 \mathrm{E}-5$ & 959.9 & $5.520 \mathrm{E}-5$ & 991.2 & 0.1 & 3.3 \\
\hline $\mathrm{E}$ & $4.385 \mathrm{E}-5$ & 1721.6 & $4.308 \mathrm{E}-5$ & 1977.2 & 1.7 & 14.8 \\
\hline \multirow[t]{2}{*}{$\mathrm{F}$} & $3.050 \mathrm{E}-5$ & 3226 & $3.861 \mathrm{E}-5$ & 4330.0 & 6.2 & 34.2 \\
\hline & & & $H=100 \mathrm{~m}$ & & & \\
\hline A & $5.528 \mathrm{E}-5$ & 132.6 & $5.684 \mathrm{E}-5$ & 122.8 & 2.5 & 7.4 \\
\hline B & $1.682 \mathrm{E}-5$ & 667 & $1.678 \mathrm{E}-5$ & 645.7 & 0.2 & 3.2 \\
\hline C & $1.563 \mathrm{E}-5$ & 1159.2 & $1.563 \mathrm{E}-5$ & 1145.2 & 0.0 & 1.2 \\
\hline $\mathrm{D}$ & $1.033 \mathrm{E}-5$ & 2537.1 & $1.032 \mathrm{E}-5$ & 2607.8 & 0.1 & 2.8 \\
\hline $\mathrm{E}$ & $5.026 \mathrm{E}-6$ & 6368.6 & $5.752 \mathrm{E}-6$ & 8285.1 & 4.5 & 30.1 \\
\hline \multirow[t]{2}{*}{$\mathrm{F}$} & $2.743 \mathrm{E}-6$ & $14,699.4$ & $2.013 \mathrm{E}-6$ & $34,757.0$ & 26.6 & 136.5 \\
\hline & & & $H=250 \mathrm{~m}$ & & & \\
\hline A & $1.427 \mathrm{E}-5$ & 231.7 & $1.382 \mathrm{E}-5$ & 213.7 & 3.2 & 7.8 \\
\hline B & $3.077 \mathrm{E}-6$ & 1605.2 & $3.067 \mathrm{E}-6$ & 1542.8 & 0.3 & 3.9 \\
\hline C & $2.638 \mathrm{E}-6$ & 3171 & $2.636 \mathrm{E}-6$ & 3107.6 & 0.1 & 2.0 \\
\hline $\mathrm{D}$ & $1.531 \mathrm{E}-6$ & 7697.4 & $1.530 \mathrm{E}-6$ & 7864.8 & 0.1 & 2.2 \\
\hline $\mathrm{E}$ & $4.491 \mathrm{E}-7$ & $41,722.4$ & $3.828 \mathrm{E}-7$ & $81,308.5$ & 14.8 & 94.9 \\
\hline $\mathrm{F}$ & $3.258 \mathrm{E}-8$ & $122,425.9$ & $5.544 \mathrm{E}-8$ & $400,312.2$ & 70.2 & 227.0 \\
\hline
\end{tabular}

Table 5. Relation between actual and estimated values for MGLC and its location using power law method (Klug system) for different stack heights.

\begin{tabular}{ccccccc}
\hline $\begin{array}{c}\text { Stability } \\
\text { class }\end{array}$ & $\begin{array}{c}C_{m a} \\
\mathrm{~g} / \mathrm{m}^{3}\end{array}$ & $\begin{array}{c}X_{m a} \\
\mathrm{~m}\end{array}$ & $\begin{array}{c}C_{m e} \\
\mathrm{~g} / \mathrm{m}^{3}\end{array}$ & $\begin{array}{c}X_{m e} \\
\mathrm{~m}\end{array}$ & $\begin{array}{c}\text { Relative } \\
C_{m}\end{array}$ & $\begin{array}{c}\text { Error\% } \\
X_{m}\end{array}$ \\
\hline & & & $H=5 \mathrm{~m}$ & & & \\
A & $2.184 \mathrm{E}-3$ & 51.2 & $2.150 \mathrm{E}-3$ & 47.8 & 1.6 & 6.6 \\
B & $3.713 \mathrm{E}-3$ & 48.9 & $3.705 \mathrm{E}-3$ & 45.3 & 0.2 & 3.3 \\
\hline
\end{tabular}




\section{Continued}

\begin{tabular}{|c|c|c|c|c|c|c|}
\hline C & $3.440 \mathrm{E}-3$ & 79.5 & $3.439 \mathrm{E}-3$ & 78.9 & 0.0 & 0.7 \\
\hline $\mathrm{D}$ & $5.085 \mathrm{E}-3$ & 83.4 & $5.084 \mathrm{E}-3$ & 84.9 & 0.0 & 1.8 \\
\hline $\mathrm{E}$ & $5.937 \mathrm{E}-3$ & 92 & $5.924 \mathrm{E}-3$ & 97.0 & 0.2 & 5.5 \\
\hline \multirow[t]{2}{*}{$\mathrm{F}$} & $5.539 \mathrm{E}-3$ & 166.5 & $5.515 \mathrm{E}-3$ & 182.1 & 0.4 & 9.4 \\
\hline & & & $H=45 \mathrm{~m}$ & & & \\
\hline A & $5.763 \mathrm{E}-5$ & 251.8 & $5.672 \mathrm{E}-5$ & 235.1 & 1.6 & 6.6 \\
\hline B & $6.143 \mathrm{E}-5$ & 403.5 & $6.129 \mathrm{E}-5$ & 389.9 & 0.2 & 3.4 \\
\hline C & $4.509 \mathrm{E}-5$ & 968.5 & $4.509 \mathrm{E}-5$ & 962.2 & 0.0 & 0.8 \\
\hline $\mathrm{D}$ & $5.614 \mathrm{E}-5$ & 1714 & $5.612 \mathrm{E}-5$ & 1743.8 & 0.0 & 1.7 \\
\hline $\mathrm{E}$ & $5.475 \mathrm{E}-5$ & 3375.5 & $5.463 \mathrm{E}-5$ & 3558.0 & 0.2 & 5.4 \\
\hline \multirow[t]{2}{*}{$\mathrm{F}$} & $4.524 \mathrm{E}-5$ & $13,482.5$ & $4.505 \mathrm{E}-5$ & $14,750.0$ & 0.4 & 9.4 \\
\hline & & & $H=100 \mathrm{~m}$ & & & \\
\hline A & $1.538 \mathrm{E}-5$ & 449.1 & $1.514 \mathrm{E}-5$ & 419.3 & 1.6 & 6.6 \\
\hline B & $1.383 \mathrm{E}-5$ & 881.6 & $1.380 \mathrm{E}-5$ & 852.3 & 0.2 & 3.3 \\
\hline C & $9.332 \mathrm{E}-6$ & 2402.8 & $9.331 \mathrm{E}-6$ & 2384.1 & 0.0 & 0.8 \\
\hline $\mathrm{D}$ & $1.092 \mathrm{E}-5$ & 5140.6 & $1.091 \mathrm{E}-5$ & 5230.1 & 0.0 & 1.7 \\
\hline $\mathrm{E}$ & $9.971 \mathrm{E}-6$ & $12,497.7$ & $9.950 \mathrm{E}-6$ & $13,137.9$ & 0.2 & 5.4 \\
\hline \multirow[t]{2}{*}{$\mathrm{F}$} & $7.884 \mathrm{E}-6$ & 66,581 & $7.850 \mathrm{E}-6$ & $75,839.6$ & 0.4 & 9.4 \\
\hline & & & $H=250 \mathrm{~m}$ & & & \\
\hline A & $3.377 \mathrm{E}-6$ & 872 & $3.324 \mathrm{E}-6$ & 814.4 & 1.5 & 6.6 \\
\hline B & $2.501 \mathrm{E}-6$ & 2162.9 & $2.495 \mathrm{E}-6$ & 2091.1 & 0.2 & 3.3 \\
\hline C & $1.531 \mathrm{E}-6$ & 6814.6 & $1.531 \mathrm{E}-6$ & 6761.6 & 0.0 & 0.8 \\
\hline $\mathrm{D}$ & $1.667 \mathrm{E}-6$ & $18,129.1$ & $1.666 \mathrm{E}-6$ & $18,445.2$ & 0.0 & 1.7 \\
\hline $\mathrm{E}$ & $1.413 \mathrm{E}-6$ & $56,129.5$ & $1.410 \mathrm{E}-6$ & $59,166.3$ & 0.2 & 5.4 \\
\hline $\mathrm{F}$ & $1.062 \mathrm{E}-6$ & 416,131 & $1.057 \mathrm{E}-6$ & $455,247.4$ & 0.4 & 9.4 \\
\hline
\end{tabular}

Table 6. Actual values for MGLC, relation between actual and estimated values for its location using standard scheme for different stack heights.

\begin{tabular}{ccccc}
\hline Stability class & $\begin{array}{c}C_{m a} \\
\mathrm{~g} / \mathrm{m}^{3}\end{array}$ & $\begin{array}{c}X_{m a} \\
\mathrm{~m}\end{array}$ & $\begin{array}{c}X_{m e} \\
\mathrm{~m}\end{array}$ & $\begin{array}{c}\text { Relative error\% } \\
X_{m}\end{array}$ \\
\hline & & $H=5 \mathrm{~m}$ & & \\
$\mathrm{~A}$ & $4.11 \mathrm{E}-3$ & 33 & -317.7 & 10.6 \\
B & $4.575 \mathrm{E}-3$ & 36.5 & -336.1 & 10.2 \\
C & $5.076 \mathrm{E}-3$ & 50 & -315.1 & 7.3 \\
D & $5.465 \mathrm{E}-3$ & 77.5 & -1321.5 & 18.05 \\
E & $5.286 \mathrm{E}-3$ & 111 & -2845.7 & 26.6 \\
F & $5.149 \mathrm{E}-3$ & 173.5 & -3900 & 23.5 \\
& & $H=45 \mathrm{~m}$ & & \\
\hline
\end{tabular}




\section{Continued}

\begin{tabular}{|c|c|c|c|c|}
\hline A & $7.350 \mathrm{E}-5$ & 223.5 & -317.7 & 2.4 \\
\hline B & $6.481 \mathrm{E}-5$ & 320.1 & -336.1 & 2.05 \\
\hline $\mathrm{C}$ & $6.438 \mathrm{E}-5$ & 491 & -315.1 & 1.64 \\
\hline $\mathrm{D}$ & $5.251 \mathrm{E}-5$ & 932.9 & -1321.5 & 2.41 \\
\hline E & $4.395 \mathrm{E}-5$ & 1476.5 & -2845.7 & 2.92 \\
\hline \multirow[t]{2}{*}{$\mathrm{F}$} & $3.166 \mathrm{E}-5$ & 2939.7 & -3900 & 1.24 \\
\hline & & $H=100 \mathrm{~m}$ & & \\
\hline A & $1.968 \mathrm{E}-5$ & 393.3 & -317.7 & 1.8 \\
\hline B & $1.467 \mathrm{E}-5$ & 689.2 & -336.1 & 1.48 \\
\hline $\mathrm{C}$ & $1.330 \mathrm{E}-5$ & 1165 & -315.1 & 1.27 \\
\hline $\mathrm{D}$ & $8.116 \mathrm{E}-6$ & 2877.2 & -1321.5 & 1.45 \\
\hline E & $5.349 \mathrm{E}-6$ & 5469.5 & -2845.7 & 1.52 \\
\hline \multirow[t]{2}{*}{$\mathrm{F}$} & $2.535 \mathrm{E}-6$ & $15,718.2$ & -3900 & 1.24 \\
\hline & & $H=250 \mathrm{~m}$ & & \\
\hline A & $4.752 \mathrm{E}-6$ & 688.5 & -317.7 & 1.46 \\
\hline B & $2.769 \mathrm{E}-6$ & 1632.4 & -336.1 & 1.2 \\
\hline C & $2.188 \mathrm{E}-6$ & 3187.7 & -315.1 & 1.09 \\
\hline $\mathrm{D}$ & $8.209 \mathrm{E}-6$ & $13,099.8$ & -1321.5 & 1.10 \\
\hline $\mathrm{E}$ & $3.236 \mathrm{E}-7$ & $41,423.9$ & -2845.7 & 1.06 \\
\hline F & $8.250 \mathrm{E}-8$ & $243,818.1$ & -3900 & 1.02 \\
\hline
\end{tabular}

Table 6 shows that the values of $x_{m e}$ estimated by Equation (13) are negative values so the approximation $\sigma_{z}=H / \sqrt{2}$ is not suitable for the standard scheme.

The values of the relative errors between the actual and estimated MGLC lie in the range from: 0 to 70.2 and 0 to 1.6 for Pasquill Gifford system and Klug system respectively. The errors between the actual and estimated location of the MGLC lies in the range from: 0.2 to 227 and 0.7 to 9.4 for Pasquill Gifford system and Klug system respectively.

From this discussion we conclude that the approximation $\sigma_{z}=H / \sqrt{2}$ is most suitable for the Klug system and Pasquill Gifford system.

\section{Conflicts of Interest}

The authors declare no conflicts of interest regarding the publication of this paper.

\section{References}

[1] World Meteorological Organization (1982) Review of Atmospheric Diffusion Models for Regulatory Application. Technical Note No. 177, by S.R. Hanna, WMO-No. 581. 
[2] Sutton, O.G. (1953) Micrometeorology. McGraw-Hill, New York, 273-295.

[3] Turner, D.B. (1970) Workbook of Atmospheric Dispersion Estimates. U.S. Public Health Service, Division of Air Pollution, Publication No. 999, AP26.

[4] Smith, F.B. (1973) A Scheme for Evaluating the Vertical Dispersion of a Plume from a Source near Ground Level. Proceedings of the 3rd Meeting of an Expert Panel on Air Pollution Modeling, Brussels, Report 14.

[5] Csanady, G.T. (1973) Effect of Plume Rise on Ground Level Pollution. Atmospheric Environment, 7, 1-16. https://doi.org/10.1016/0004-6981(73)90192-3

[6] Mayhoub, A.B., Embaby, M., Essa, K.S.M. and Etman, S. (2009) Maximum Ground Level Concentration of Air Pollutant. Atmosfera, 15, 185-191.

[7] Essa, K.S.M. and Etman, S.M. (2013) Crosswind Integrated Concentration for Various Dispersion Parameter Systems. Mausam, 64, 645-654. https://doi.org/10.1002/maco.201370012

[8] IAEA (1980) Atmospheric Dispersion in Nuclear Power Plant Sitting. A Safety Guide No. 50-SG-S3, Vienna.

[9] Lines, I.G., Deaves, D.M. and Atkins, W.S. (1997) Practical Modelling of Gas Dispersion in Low Wind Speed Conditions, for Application in Risk Assessment. Journal of Hazardous Materials, 54, 201-226. https://doi.org/10.1016/S0304-3894(96)01873-0

[10] Kenneth, W. and Cecil, F.W. (1972) Air Pollution Its Original and Control. Adun-Donnelly Publisher, New York.

[11] Apiratikul, R. (2015) Approximation Formula for Prediction of Downwind Distance That Found the Maximum Ground Level Concentration of Air Pollution Based on the Gaussian Model. Procedia-Social and Behavioral Sciences, 197, 1257-1262. https://doi.org/10.1016/j.sbspro.2015.07.397

[12] Pasquil, F. (1961) The Estimation of the Dispersion of Windborne Material. $\mathrm{Me}$ teorological Magazine, 90, 33.

[13] Gifford, F. (1961) Use of Routine Meteorological Observations for Estimating Atmospheric Dispersion. Nuclear Safety, 2, 44-57.

[14] Vogt, K.J. (1977) Empirical Investigations of the Diffusion of Waste Air Plumes in the Atmosphere. Nuclear Technology, 34, 43-57. https://doi.org/10.13182/NT77-A31828

[15] Till, J.E. and Mater, R.H. (1983) Radiological Assessment. A Textbook on Environmental Dose Analysis. NUREG/CR-3332, ORNL-5968. https://doi.org/10.2172/5407895

[16] Klug, W. (1969) Ein Verfahren zur Bestimung der Ausbreitungsbedingungen aus synoptisch Beobachtungen. Staub-Reinhaltung der Luft, 29, 143-147.

[17] Green, A.E.S., Singhal, R.P. and Venkateswar, R. (1980) Analytic Extensions of the Gaussian Plume Model. Journal of the Air Pollution Control Association, 30, 773-776. https://doi.org/10.1080/00022470.1980.10465108 